Supporting Information

\title{
Effect of tungsten and carbon in germanium oxide as a high-performance electrode for energy storage application
}

\author{
Diwakar Karuppiah, Rajkumar Palanisamy, Subadevi Rengapillai*, Arjunan Ponnaiah, \\ Sivakumar Marimuthu* \\ \#120 Energy material lab, Department of Physics, Alagappa University, Karaikudi-630003, \\ Tamil Nadu, India. \\ *Corresponding Author(s): Email: \\ 1) susiva73@yahoo.co.in \& sivakumarm@alagappauniversity.ac.in (Sivakumar Marimuthu); \\ 2)susimsk@yahoo.co.in \& subadevir@alagappauniversity.ac.in (Subadevi Rengapillai)
}

\section{The cell fabrication for LIBs and SIBs}

The electrode was fabricated by using $80 \mathrm{wt} \%$ active materials mixed with $10 \mathrm{wt} \%$ Super-P carbon and $10 \mathrm{wt} \%$ poly (vinylidene flouride) (PVdF) binder. Initially, binder PVdF was dissolved in N-methyl pyrrolidone (NMP) to obtain the uniform dispersion in the solvent, and the pre-mixed active material with Super-P has been mixed with the binder solution to get homogenous slurry. The resultant slurry was coated on a Copper $(\mathrm{Cu})$ foil, which acts as a current collector with the active mass of electrode is $3.863 \mathrm{mg}$. To evaporate the solvent, the coated slurry was dried under vacuum at $80{ }^{\circ} \mathrm{C}$ for $12 \mathrm{~h}$; the electrode was then roll-pressed using 3 Ton pressure. The hot roll pressed electrode was cut down as circular discs with $14 \mathrm{~mm}$ diameter. Further, the electrode was dried under vacuum at $80{ }^{\circ} \mathrm{C}$ for $3 \mathrm{~h}$ before assembling cells in an Argon filled glove box. Electrochemical characterization was carried out on freshly fabricated 2032 coin cells consisting of $\mathrm{GeO}_{2} @ \mathrm{~W}$ and $\mathrm{GeO}_{2} @ \mathrm{~W} @ \mathrm{C}$ as a anode vs. Li (for SIB, anode vs. $\mathrm{Na}$ ) and a non-aqueous electrolyte containing $1 \mathrm{M} \mathrm{LiClO}_{4}$ and $1 \mathrm{M}$ of $\mathrm{NaClO}_{4}$ (dissolved in 1:1 v/v EC:PC) using polypropylene and glass fiber as a separator. 


\section{The electrode fabrication for supercapacitor}

All the weight ratios are the same for the supercapacitor application, except the active material paste coated on the Nickel foam instead of copper foil in batteries. After drying the Nifoam overnight, the working electrode is ready to perform the electrochemical analysis using three-electrode systems with $\mathrm{Pt}$ (counter electrode) and $\mathrm{Ag} / \mathrm{AgCl}$ (reference electrode) in the $3 \mathrm{M}$ of $\mathrm{KOH}$ as an electrolytic solution.

Table S1.XPS elemental ratios for the ternary composite $\left(\mathrm{GeO}_{2} @ \mathrm{~W} @ \mathrm{C}\right)$

\begin{tabular}{|c|c|c|c|}
\hline Name & FWHM & Area & Atomic \% \\
\hline Ge 3d & 2.87 & 168849 & 7.66 \\
\hline W 4f & 4.84 & 352940 & 3.35 \\
\hline C 1s & 3.92 & 666126 & 43.3 \\
\hline O 1s & 5.25 & 90892 & 45.68 \\
\hline
\end{tabular}
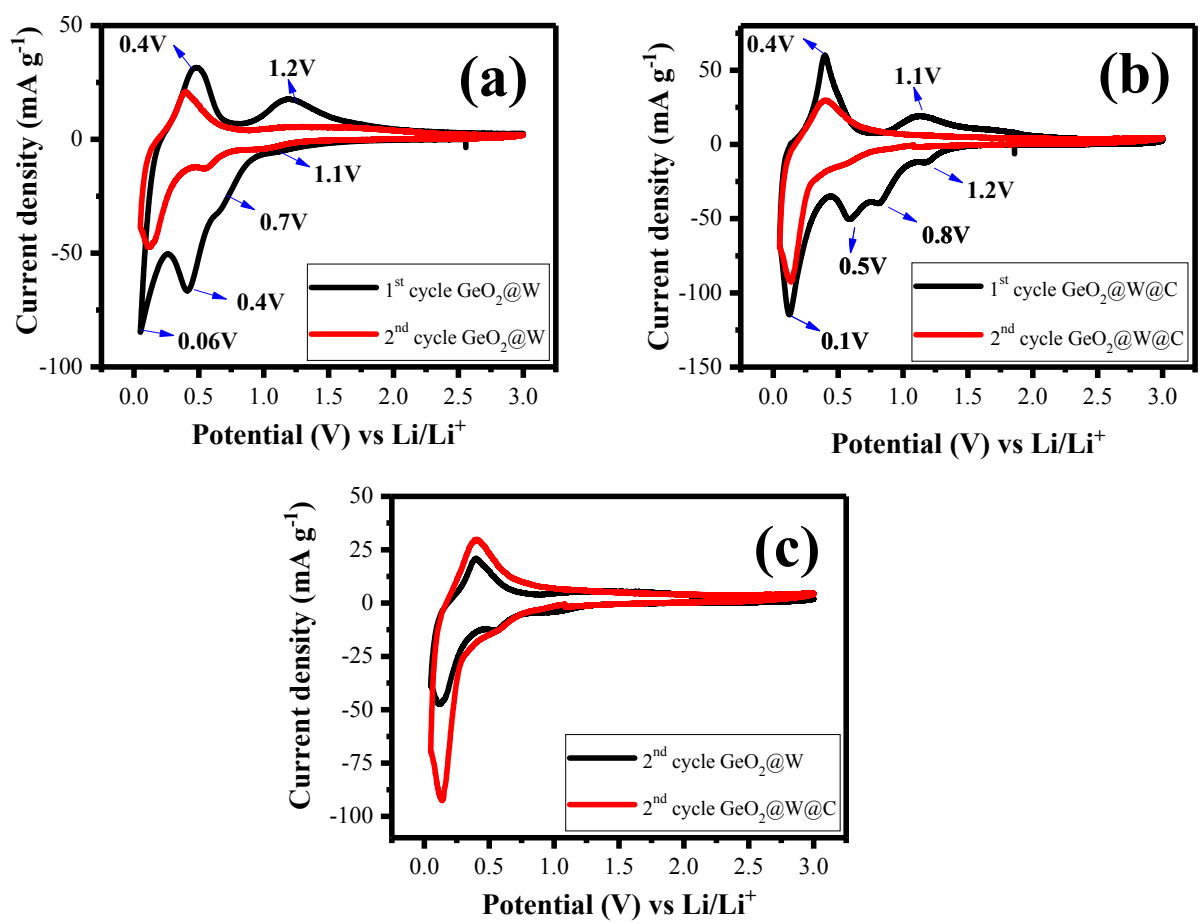

Figure $\mathrm{S} 1(\mathrm{a}, \mathrm{b}) \mathrm{CV}$ curve of $1^{\text {st }}$ and $2^{\text {nd }}$ cycles at a scan rate of $0.1 \mathrm{mV} \mathrm{s}^{-1}$ within the potential

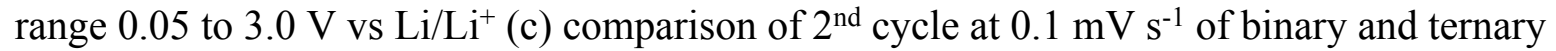
composite. 
Table S2 Equivalent circuit components of the binary and ternary composite for LIBs

\begin{tabular}{|c|c|c|}
\hline Elements & $\begin{array}{c}\text { Binary composite } \\
\mathrm{GeO}_{2} @ \mathrm{~W}\end{array}$ & $\begin{array}{c}\text { Ternary composite } \\
\mathrm{GeO}_{2} @ \mathrm{~W} @ \mathrm{C}\end{array}$ \\
\hline Solution resistance - $\mathrm{R} 1(\Omega)$ & 7.6 & 11.6 \\
\hline Charge transfer resistance $-\mathrm{R} 2(\Omega)$ & 211.3 & 74.8 \\
\hline Constant phase element - Q2 $\left(\mu \mathrm{F} \mathrm{s} \mathrm{s}^{(\mathrm{a}-1)}\right)$ & 19.4 & 71.4 \\
\hline Warburg impedance - W2 $\left(\Omega \cdot \mathrm{s}^{-1 / 2}\right)$ & 165.3 & 95.1 \\
\hline
\end{tabular}
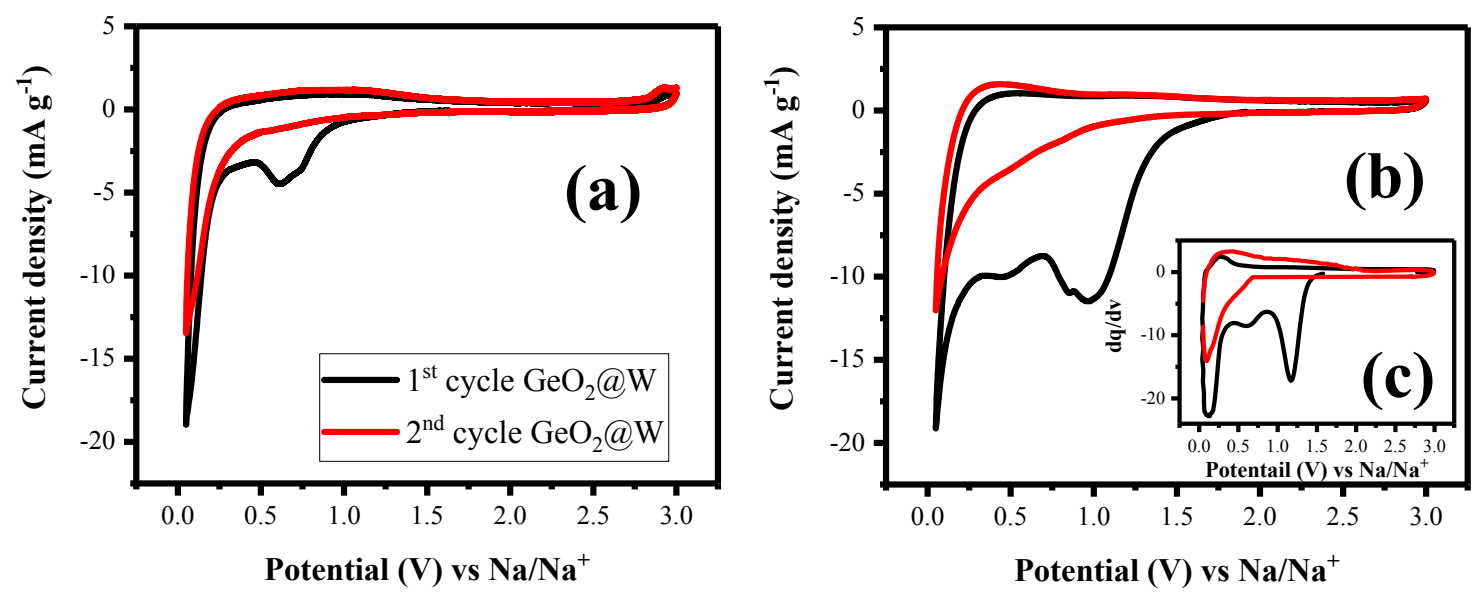

Figure S2 $(\mathrm{a}, \mathrm{b}) \mathrm{CV}$ curve of $1^{\text {st }}$ and $2^{\text {nd }}$ cycles at a scan rate of $0.1 \mathrm{mV} \mathrm{s}^{-1}$ within the potential range 0.05 to $3.0 \mathrm{~V}$ vs Na/Na+ $\mathrm{Na}^{+}$binary and ternary composite, inset (c) dQ/dV profile of ternary composite electrode as an anode at $100 \mathrm{~mA} \mathrm{~g}^{-1}$.

Table S3 Equivalent circuit components of the binary and ternary composite for SIBs

\begin{tabular}{|c|c|c|}
\hline Elements & $\begin{array}{c}\text { Binary composite } \\
\mathrm{GeO}_{2} @ \mathrm{~W}\end{array}$ & $\begin{array}{c}\text { Ternary composite } \\
\mathrm{GeO}_{2} @ \mathrm{~W} @ \mathrm{C}\end{array}$ \\
\hline Solution resistance - $\mathrm{R} 1(\Omega)$ & 18.1 & 12.9 \\
\hline Charge transfer resistance $-\mathrm{R} 2(\Omega)$ & 290.1 & 91.5 \\
\hline Constant phase element - Q2 $\left(\mu \mathrm{F} \mathrm{s} \mathrm{s}^{(\mathrm{a}-1)}\right)$ & 74.2 & 91.4 \\
\hline Warburg impedance - W2 $\left(\Omega . \mathrm{s}^{-1 / 2}\right)$ & 110.8 & 68.07 \\
\hline
\end{tabular}


Table S4 Equivalent circuit and its component parameters of ternary composite for SCs

\begin{tabular}{|c|c|}
\hline Elements & $\begin{array}{c}\text { Ternary composite } \\
\mathrm{GeO}_{2} @ \mathrm{~W} @ \mathrm{C}\end{array}$ \\
\hline Solution resistance - R1 $(\Omega)$ & 0.37 \\
\hline Charge transfer resistance - R2 $(\Omega)$ & 1.98 \\
\hline Capacitor- C2 $(\mathrm{F})$ & 0.129 \\
\hline Warburg impedance - W2 $\left(\Omega . \mathrm{s}^{-1 / 2}\right)$ & 11.1 \\
\hline
\end{tabular}

